\title{
Standar Perencanaan dan Implementasi Keperawatan dalam Pemenuhan Kepuasaan Pasien
}

\section{Emyranda Samosir}

emyrandasamosir@gmail.com

\begin{abstract}
Hasil penelitian Badan Pusat Statistik (2015) bahwa persentase penduduk yang mengalami keluhan kesehatan dari tahun 2012 hingga 2015 mengalami peningkatan, yakni 28.84\% (2012), $27.94 \%$ (2013), 29.22\% (2014), 30.35\% (2015). Berdasarkan keadaan tersebut kebutuhan masyarakat akan layanan kesehatan akan ikut meningkat. Salah satu outcome dari layanan kesehatan selain kesembuhan pasien adalah kepuasan pasien (Pohan, 2007). Penurunan jumlah pasien merupakan salah satu indikasi dari ketidakpuasan pasien pada pelayanan puskesmas walaupun tidak signifikan dalam membuktikan kepuasan atau ketidakpuasan pasien.Asuhan keperawatn sangat mempengaruhi kepuasan pasien. Keperawatan digunakan secara terus-menerus ketika merencanakan dan memberikan asuhan keperawatan dengan mempertimbangkan pasien sebagai figur central dalam merencanakan asuhan dengan mengobservasi respons pasien terhadap setiap tindakan sebagai penatalaksanaan dalam suatu asuhankeperawatan.Perencanaan keperawatan yang tepat dapat menjadi tahap yang tepat dalam menggembangkan asuhan keperawatan selanjutnya yaitu implementasi.Pada saat implementasi perawat harus melaksanakan hasil dari rencana keperawatan yang di lihat dari diagnosa keperawatan.
\end{abstract}

Kata Kunci : Perencanaan Keperawatan ,Implementasi Keperawatan ,Kepuasan Pasien 


\section{Latar Belakang}

\begin{abstract}
Keperawatan merupakan suatu bentuk pelayanan profesional bersifat humanistik, menggunakan pendekatan holistik, dilakukan berdasarkan ilmu dan kiat keperawatan, berorientasi kepada kebutuhan objektif klien. Praktek keperawatan mengacu pada standar professional keperawatan dan menggunakan etika keperawatan sebagai tuntutan utama. Perawat dituntut untuk selalu melaksanakan asuhan keperawatan yang benar atau rasional (Nursalam, 2007). Proses asuhan keperawatan merupakan tugas dan kewajiban seorang perawat dari pasien datang sampai pasien pulang, dimulai dengan pengkajian secara menyeluruh, kemudian menegakkan diagnosa keperawatan dari data pengkajian tersebut, serta melaksanakan intervensi, implementasi dan evaluasi keefektifan diagnosa awal yang sudah ditegakkan (Nursalam, 2007).
\end{abstract}

Asuhan keperawatan adalah faktor penting dalam kelangsungan hidup pasien dan aspek-aspek pemeliharaan, rehabilitatif dan prefentif perawatan kesehatannya. Menurut Shore, untuk sampai pada hal ini, profesi keperawatan telah mengidentifkasi proses pemecahan masalah yang "menggabungkan elemen yang paling diinginkan dari seni keperawatan dengan elemen yang paling relevan dari sistem teori, dengan menggunakan metode ilmiah".

Pelaksanaan asuhan keperawatan profesional diwujudkan dengan menerapkan model praktek keperawatan profesional (MPKP) disetiap ruangan. Menurut Ratna Sitorus (2006 dikutip Nursalam 2007), MPKP adalah suatu sistem (struktur, proses dan nilai-nilai profesional), yang memfasilitasi perawat profesional, mengatur pemberian asuhan keperawatan termasuk lingkungan tempat asuhan keperawatan tersebut.

Perencanaan keperawatan adalah suatu proses di dalam pemecahan masalah yang merupakan keputusan awal tentang sesuatu apa yang akan dilakukan, bagaimana dilakukan, kapan dilakukan, siapa yang melakukan dari semua tindakan keperawatan (Dermawan, 2012).Setelah perencanaan,Langkah selanjutnya ialah Implementasi keperawatan.

Implementasi keperawatan adalah kegiatan mengkoordinasikan aktivitas pasien, keluarga, dan anggota tim kesehatan lain untuk mengawasi dan mencatat respon pasien terhadap tindakan keperawatan yang 
telah dilakukan (Nettina, 2002). Jadi, implemetasi keperawatan adalah kategori serangkaian perilaku perawat yang berkoordinasi dengan pasien, keluarga, dan anggota tim kesehatan lain untuk membantu masalah kesehatan pasien yang sesuai dengan perencanaan dan kriteria hasil yang telah ditentukan dengan cara mengawasi dan mencatat respon pasien terhadap tindakan keperawatan yang telah dilakukan.

Menurut Kotler dan Keller (2009), kepuasan pelanggan (customer satisfaction) diartikan sebagai fungsi dari seberapa sesuainya harapan pembeli produk dengan kinerja yang dipikirkan pembeli atas produk tersebut. Westbrook dan Reilly juga memberikan definisi atau pengertian kepuasan pelanggan (customer satisfaction) sebagai respons emosional terhadap pengalaman-pengalaman berkaitan dengan produk atau jasa tertentu yang dibeli, gerai ritel, atau bahkan pola perilaku (seperti perilaku berbelanja dan perilaku pembeli), serta pasar secara keseluruhan (dalam Tjiptono 2008).

\section{Tujuan}

Tujuan rencana tindakan dibagi menjadi dua menurut Dermawan (2012) yaitu:

a) Tujuan administratif
(1) Untuk mengidentifikasi fokus keperawatan kepada pasien atau kelompok.

(2) Untuk membedakan tanggungjawab perawat dengan profesi kesehatan lainnya.

(3) Untuk menyediakan suatu kriteria guna pengulangan dan evaluasi keperawatan.

(4) Untuk menyediakan kriteria klasifikasi pasien.

b) Tujuan klinik

(1) Menyediakan suatu pedoman dalam penulisan.

(2) Mengkomunikasikan dengan staf perawat; apa yang diajarkan, diobservasi dan dilaksanakan.

(3) Rencana tindakan yang spesifik secara langsung bagi individu, keluarga, dan tenaga kesehatan lainnya untuk melaksanakan tindakan.

\section{Metode}

Rancangan penugasan kajian ini menggunakan literature review berdasarkan buku teks, buku referensi, jurnal, e-book (yang dipublikasikan 10 tahun terakhir) dan menggunakan dua belas sumber referensi dengan menganalisis, eksplorasi, dan kajian bebas sesuai dengan judul penugasan kajian ini 


\section{Hasil}

Pelayanan prima adalah kepedulian kepada pasien dengan memberikan layanan terbaik untuk memfasilitasi kemudahan pemenuhan kebutuhan dan mewujudkan kepuasannya (Barata, 2003). Pelayanan kesehatan bertujuan untuk mengatasi masalah kesehatan seseorang.Asuhan keperawatan memiliki dampak yang signifikan terhadap kepuasan pasien.Ada 4 tingkat kepuasan pasien yaitu : $\quad$ Sangat memuaskan,memuaskan,tidak memuaskan,sangat tidak memuaskan.

Perencanaan keperawatan adalah bagian dari fase pengorganisasian dalam proses keperawatan sebagai pedoman untuk mengarahkan tindakan keperawatan dalam usaha membantu, meringankan, memecahkan masalah atau untuk memenuhi kebutuhan pasien (Setiadi, 2012).

\section{Terdapat 3 langkah Perencanaan} keperawatan yaitu meliputi : Menentukan prioritas masalah ,Menentukan tujuan dan kriteria hasil, Memilih rencana tindakan atau intervensi keperawatan.

Keberhasilan perawat dalam melakukan implementasi tergantung dari perencanaan yang telah dikonsepkan perawat terhadap kebutuhan yang sesuai dengan pasiennya.
Pedoman implementasi keperawatan menurut Dermawan (2012) sebagai berikut:

a) Tindakan yang dilakukan konsisten dengan rencana dan dilakukan setelah memvalidasi rencana.

b) Keterampilan interpersonal, intelektual dan teknis dilakukan dengan kompeten dan efisien di lingkungan yang sesuai.

c) Keamanan fisik dan psikologis pasien dilindungi.

d) Dokumentasi tindakan dan respon pasien dicantumkan dalam catatan perawatan kesehatan dan rencana asuhan.

\section{Pembahasan}

Kepuasan pasien merupakan perasaan yang dimiliki pasien dan timbul sebagai hasil dari kinerja layanan kesehatan setelah pasien membandingkannya dengan apa yang diharapkan (Pohan, 2007). Hasil tersebut berupa respon dari pasien terhadap pelayanan kesehatan yang diterima secara nyata. Pelayanan kesehatan yang dimaksud dalam penelitian ini yakni pelayanan keperawatan. Pelayanan keperawatan yang diterima oleh pasien ternyata lebih buruk dari harapan pasien, maka pasien tersebut merasa tidak puas karena merasa kecewa. Apabila 
pelayanan keperawatan yang diterima oleh pasien ternyata sebanding dengan harapan pasien maka pasien merasa puas (senang). Kepuasan pasien adalah suatu prioritas yang akan membantu perawat dalam memberikan pelayanan keperawatan agar pasien mau berparisipasi selama perawatan.

Menurut Gerson (2002), untuk mengetahui tingkat kepuasan pelanggan dapat diklasifikasikan dalam beberapa tingkatan sebagai berikut :

\section{Sangat memuaskan}

Diartikan sebagai ukuran subjektif hasil penilaian perasaan pasien yang menggambarkan pelayanan kesehatan sepenuhnya atau sebagian besar sesuai kebutuhan atau keinginan pasien, seperti sangat bersih (untuk prasarana), sangat ramah (untuk hubungan dengan dokter atau perawat), atau sangat cepat (untuk proses administrasi), yang seluruhnya menggambarkan tingkat kualitas pelayanan yang paling tinggi.

\section{Memuaskan}

Diartikan sebagai ukuran subjektif hasil penilaian perasaan pasien, yang menggambarkan pelayanan kesehatan tidak sepenuhnya atau sebagian sesuai kebutuhan atau keinginan seperti tidak terlalu bersih (untuk sarana), agak kurang cepat (proses administrasi), atau kurang ramah, yang seluruhnya ini menggambarkan tingkat kualitas yang kategori sedang.

3. Tidak memuaskan

Diartikan sebagai ukuran subjektif hasil penilaian perasaan pasien rendah, yang menggambarkan pelayanan kesehatan tidak sesuai kebutuhan atau keinginan seperti tidak terlalu bersih (untuk sarana), agak lambat (untuk proses administrasi), atau tidak ramah.

\section{Sangat tidak memuaskan.}

Diartikan sebagai ukuran subjektif hasil penilaian perasaan pasien yang rendah, menggambarkan pelayanan kesehatan tidak sesuai kebutuhan atau keinginan seperti tidak bersih (untuk sarana), lambat (untuk proses administrasi), dan tidak ramah. Seluruh hal ini menggambarkan tingkat kualitas yang kategori paling rendah.

Kurangnya kepuasaan pasien salah satunya disebabkan oleh faktor dari perawat sendiri.Salah satunya ialah perawat tidak sepenuhnya melakukan asuhan keperawatan sesuai dengan SOP.Sesuai dengan defenisi dari asuhan keperawatan yaitu suatu pendekatan untuk pemecahan masalah pada pasien dengan memberikan pelayanan keperawatan.Sesuai SOP, perawat memiliki Langkah-langkah asuhan kepeawatan yaitu : Pengkajian,Diagnosa,Perencanaan,Impleme ntasi dan evaluasi. Sering kali perawat gagal 
dalam melakukan perencanaan keperawatan yang cepat tepat kepada pasien sesuai kebutuhan pasien mengakibatkan implementasi yang buruk dalam asuhan keperawatan yang dilakukan perawat.

Perencanaan keperawatan adalah rencana tindakan keperawatan tertulis yang menggambarkan masalah kesehatan pasien, hasil yang akan diharapkan, tindakantindakan keperawatan dan kemajuan pasien secara spesifik (Manurung, 2011).

Langkah - langkah perencanaan keperawatan menurut Manurung (2011) adalah sebagai berikut:

a) Menentukan prioritas masalah.

Prioritas keperawatan adalah penyusunan diagnosa keperawatan atau masalah pasien dengan menggunakan tingkat kedaruratan atau kepentingan untuk memperoleh tahapan intervensi keperawatan yang dibutuhkan.

Saat menentukan prioritas diagnosa keperawatan digunakan standar prioritas kebutuhan dari Maslow, sebagai berikut :

Prioritas 1 : masalah yang berhubungan dengan kebutuhan fisiologis seperti respirasi, sirkulasi, nutrisi, hidrasi, eliminasi, suhu dan kesenjangan fisik.

Prioritas $2:$ masalah yang berpengaruh pada keselamatan dan keamanan.

Prioritas 3 : masalah yang berpengaruh terhadap cinta dan rasa memiliki.
Prioritas 4 : masalah yang berpengaruh pada rasa harga diri.

Prioritas 5 : masalah yang berpengaruh pada kemampuan mencapai sasaran pribadi atau aktualisasi diri.

Pengurutan prioritas akan dipengaruhi oleh faktor-faktor persepsi pasien terhadap prioritas, untuk itu menanyakan kepada pasien tentang apa yang dirasakannya merupakan hal yang penting.

b) Menuliskan tujuan dan kriteria hasil.

Tujuan perawatan adalah hasil yang diinginkan dari asuhan keperawatan yang diharapkan dapat dicapai bersama pasien serta direncanakan untuk mengurangi masalah yang telah diidentifikasi dalam diagnosis keperawatan (Manurung, 2011).

Saat merumuskan tujuan, ada beberapa petunjuk umum yang perlu diperhatikan menurut Manurung (2011), yaitu :

(1) Tujuan dinyatakan dengan istilah hasil yang ingin dicapai, bukan tindakan keperawatannya.

(2) Tujuan keperawatan harus menggambarkan perilaku pasien yang dapat diamati dan diukur.

(3) Tujuan harus realistis, mencerminkan kemampuan dan keterlibatan pasien. 
(4) Setiap tujuan berdasarkan dari satu diagnosis keperawatan.

Kriteria hasil mempunyai ciri-ciri menurut Dermawan (2012) yaitu setiap kriteria hasil berhubungan dengan tujuan yang telah ditetapkan, hasil yang ditetapkan dalam kriteria hasil, memungkinkan untuk dicapai, setiap kriteria hasil adalah pernyataan satu hal yang spesifik, kriteria harus sekonkrit mungkin untuk memudahkan pengukuran, kriteria cukup besar atau dapat diukur, kriteria menggunakan kata-kata positif bukan menggunakan kata negatif.

Pedoman penulisan kriteria hasil menurut Setiadi (2012) adalah berfokus pada pasien, singkat dan jelas, dapat diobservasi dan dapat diukur, ada batas waktu, ditentukan oleh perawat dan pasien.

c) Memilih rencana tindakan atau intervensi keperawatan.

(1) Tindakan keperawatan harus aman bagi pasien.

(2) Tindakan keperawatan harus sejalan dengan tindakan pengobatan.

(3) Tindakan keperawatan harus didasari prinsip dan pengetahuan yang digabungkan dari pendidikan dan pengalaman sebelumnya.
(4) Tulis sekumpulan tindakan keperawatan untuk mencapai setiap tujuan.

(5) Pilih satu kumpulan tindakan keperawatan yang kiranya cocok dengan sikap yang disebutkan dalam pernyataan tujuan.

(6) Tindakan keperawatan harus realistis.

(7) Tindakan keperawatan harus penting bagi peningkatan kesehatan pasien dan sejalan dengan tujuan serta nilai perseorangan pasien.

(8) Gunakan pasien sebagai sumber-sumber dalam memilih tindakan keperawatan.

(9) Tulis tindakan keperawatn secara berurutan.

Implementasi keperawatan adalah pelaksanaan rencana keperawatan oleh perawat dan pasien (Riyadi, 2010).

Implementasi keperawatan adalah pengelolaan dan perwujudan dari rencana keperawatan yang telah disusun pada tahap perencanaan (Setiadi, 2012). Pedoman implementasi keperawatan menurut Dermawan (2012) sebagai berikut:

a) Tindakan yang dilakukan konsisten dengan rencana dan dilakukan setelah memvalidasi rencana. 
Validasi menentukan apakah rencana masih relevan, masalah mendesak, berdasar pada rasional yang baik dan diindividualisasikan. Perawat memastikan bahwa tindakan yang sedang diimplementasikan, baik oleh pasien, perawat atau yang lain, berorientasi pada tujuan dan hasil. Tindakan selama implementasi diarahkan untuk mencapai tujuan.

b) Keterampilan interpersonal, intelektual dan teknis dilakukan dengan kompeten dan efisien di lingkungan yang sesuai.

Perawat harus kompeten dan mampu melaksanakan keterampilan ini secara efisien guna menjalankan rencana. Kesadaran diri dan kekuatan serta keterbatasan perawat menunjang pemberian asuhan yang kompeten dan efisien sekaligus memerankan peran keperawatan profesional.

c) Keamanan fisik dan psikologis pasien dilindungi.

Selama melaksanakan implementasi, keamanan fisik dan psikologis dipastikan dengan mempersiapkan pasien secara adekuat, melakukan asuhan keperawatan dengan terampil dan efisien, menerapkan prinsip yang baik, mengindividualisasikan tindakan dan mendukung pasien selama tindakan tersebut. d) Dokumentasi tindakan dan respon pasien dicantumkan dalam catatan perawatan kesehatan dan rencana asuhan.

Dokumentasi dalam catatan perawatan kesehatan terdiri atas deskripsi tindakan yang diimplementasikan dan respon pasien terhadap tindakan tersebut. Tindakan yang tidak diimplementasikan juga dicatat disertai alasan. Dokumentasi rencana asuhan untuk meningkatkan kesinambungan asuhan dan untuk mencatat perkembangan pasien guna mencapai kriteria hasil.

Tahap pelaksanaan dimulai setelah rencana tindakan disusun dan ditujukan pada nursing orders untuk membantu klien mencapai tujuan yang diharapkan. Oleh karena itu rencana tindakan yang spesifik dilaksanakan untuk memodifikasi faktor-faktor yang mempengaruhi masalah kesehatan klien. Tipe implementasi keperawatan Secara garis besar terdapat tiga kategori dari implementasi keperawatan (Craven dan Hirnle, 2000) antara lain:

\section{A.Cognitive implementations}

Pengajaran atau pendidikan, menghubungkan tingkat pengetahuan klien dengan kegiatan hidup sehari-hari, membuat strategi untuk klien 
dengan disfungsi komunikasi, memberikan umpan balik, mengawasi tim keperawatan, mengawasi penampilan klien dan keluarga, serta menciptakan lingkungan sesuai kebutuhan, dan lain lain.

\section{B. Interpersonal implementations}

Koordinasi kegiatan-kegiatan, meningkatkan pelayanan, menciptakan komunikasi terapeutik, menetapkan jadwal personal, pengungkapan perasaan, memberikan dukungan spiritual, bertindak sebagai advokasi klien, role model, dan lain lain.

C.Technical implementations yaitu Meliputi pemberian perawatan kebersihan kulit, melakukan aktivitas rutin keperawatan, menemukan perubahan dari data dasar klien, mengorganisir respon klien yang abnormal, melakukan tindakan keperawatan mandiri, kolaborasi, dan rujukan, dan lain-lain.

Dalam pelaksanaannya terdapat tiga jenis implementasi keperawatan, antara lain:

a. Independent implementations adalah implementasi yang diprakarsai sendiri oleh perawat untuk membantu klien dalam mengatasi masalahnya sesuai dengan kebutuhan, misalnya: membantu dalam memenuhi activity daily living (ADL), memberikan perawatan diri, mengatur posisi tidur, menciptakan lingkungan yang terapeutik, memberikan dorongan motivasi, pemenuhan kebutuhan psiko-sosio-spiritual, perawatan alat invasive yang dipergunakan klien, melakukan dokumentasi, dan lain-lain. b. Interdependen/ Collaborative implementations adalah tindakan keperawatan atas dasar kerjasama sesama tim keperawatan atau dengan tim kesehatan lainnya, seperti dokter. Contohnya dalam hal pemberian obat oral, obat injeksi, infus, kateter urin, naso gastric tube (NGT), dan lain-lain. Keterkaitan dalam tindakan kerjasama ini misalnya dalam pemberian obat injeksi, jenis obat, dosis, dan efek samping merupakan tanggungjawab dokter tetapi benar obat, ketepatan jadwal pemberian, ketepatan cara pemberian, ketepatan dosis pemberian, dan ketepatan klien, serta respon klien setelah pemberian merupakan tanggung jawab dan menjadi perhatian perawat.

c. Dependent implementations adalah tindakan keperawatan atas dasar rujukan dari profesi lain, seperti ahli gizi, physiotherapies, psikolog dan sebagainya, misalnya dalam hal: pemberian nutrisi pada klien sesuai dengan diit yang telah dibuat oleh ahli gizi, latihan fisik (mobilisasi fisik) sesuai dengan anjuran dari bagian fisioterapi.

Ada tiga prinsip pedoman implementasi keperawatan (Haryanto,2007), yaitu : 
a. Mempertahankan keamanan klien dengan Keamanan merupakan focus utama dalam melakukan tindakan. Oleh karena, tindakan yang membahayakan tidak hanya dianggap sebagai pelanggaran etika standar keperawatan professional, tetapi juga merupakan suatu tindakan pelanggaran hukum yang dapat ditutut.

b. Memberikan asuhan yang efektif dengan memberikan asuhan yang efektif adalah memberiakan asuhan sesuai dengan yang harus dilakukan semakin baik pengetahuan dan pengalaman seorang perawat, maka semakin efektif asuhan yang diberikan.

c. Memberikan asuhan seefisien mungkin dengan memberikan asuhan yang efisien berarti perawat dalam memberikan asuhan dapat mengunakan waktu sebaik mungkin sehingga dapat menyelesaikan masalah kilen.

Tahap - Tahap Implementasi

a. Tahap I: Review tindakan keperawatan yang diidentifikasi pada tahap perencanaan, menganalisa pengetahuan dan ketrampilan keperawatan yang diperlukan, mengetahui komplikasi dari tindakan keperawatan yang mungkin timbul, menentukan dan mempersiapkan peralatan yang diperlukan, mempersiapkan lingkungan yang kondusif sesuai dengan tindakan, dan mengidentifikasi aspek hukum dan etik terhadap resiko dari potensi tindakan. b. Tahap II: Intervensi merupakan tahap yang berfokus pada pelaksanaan tindakan perawatan adalah kegiatan pelaksanaan tindakan dari perencanaan untuk memenuhi kebutuhan fisik dan emosional.

c. Tahap III: Dokumentasi merupakan pelaksanaan tindakan keperawatan harus diikuti oleh pencatatan yang lengkap dan akurat terhadap suatu kejadian dalam proses keperawatan.

Metode Implementasi antara lain : (1) membantu dalam Aktivitas Kehidupan Sehari-Hari merupakan aktivitas Kehidupan Sehari-Hari (AKS) adalah aktivitas yang biasanya dilakukan sepanjang hari/normal, aktivitas tersebut menyangkut : ambulasi, makan, berpakaian, mandi, menyikat gigi, dan berhias.

(2) Konseling merupakan metoda implementasi yang membantu klien menggunakan proses pemecahan masalah untuk mengenali dan menangani stres dan yang memudahkan hubungan interpersonal diantara klien, keluarga dan tim perawat kesehatan. Klien dengan diagnosa psikiatris membutuhkan terapi oleh perawat yang mempunyai keahlian dalam keperaatan psikiatris oleh pekerja social, psikiater dan psikolog.

(3) Penyuluhan Digunakan menyajikan prinsip, prosedur dan teknik yang tepat 
tentang perawatan kesehatan untuk klien dan untuk menginformasikan klien tentang status kesehatanya.

\section{(4) Memberikan Asuhan Keperawatan} Langsung untuk mencapai tujuan terapeutik klien, perawat melakukan intervensi untuk mengurangi reaksi yang merugikan dengan menggunakan tindakan pencegahan dan preventive dalam memberikan asuhan.

\section{Kesimpulan}

Kepuasan pasien adalah suatu prioritas yang akan membantu perawat dalam memberikan pelayanan keperawatan agar pasien mau berparisipasi selama perawatan. Implemetasi keperawatan adalah kategori serangkaian perilaku perawat yang berkoordinasi dengan pasien, keluarga, dan anggota tim kesehatan lain untuk membantu masalah kesehatan pasien yang sesuai dengan perencanaan dan kriteria hasil yang telah ditentukan dengan cara mengawasi dan mencatat respon pasien terhadap tindakan keperawatan yang telah dilakukan. implementasi pelaksanaan kegiatan dibagi dalam beberapa kriteria yaitu: Dependen Interventions: dilaksanakan dengan mengikuti order dari pemberi perawatan kesehatan lain, Collaborative (interdependen): interpensi yang dilaksanakan dengan professional kesehatan lainnya, dan Independent (autonomous) Intervention: intervensi dilakukan dengan melakukan nursing orders dan sering juga digabungkan dengan order dari medis.

\section{Daftar Pustaka}

Agustin,R.(2017).

Optimalisasi Pelaksanaan Discharge

Planning Melalui Pengembangan Model Discharge Planning Terintegrasi Pelayanan Keperawatan.Jurnal Keperawatan Muhammadiyah.2 (1).98-100

Astar,F.et.al (2016).

Pengaruh Pelayanan Asuhan

Keperawatan Terhadap Kepuasan

Pasien Di Puskesmas Takalala Kabupaten Soppeng.Journal Of Management .1 (2).35-36

Azhar,S.et.al. (2018)

Implementasi Rencana Strategis Pelayanan Keperawatan Dalam Perspektif Kepemimpinan Kepala Ruangan Berbasis Budaya Organisasi

Di Rumah Swasta.Caring Nursing Jurnal.2(2).57-58 
Bumolo,M.(2017).

Pengaruh Manajemen Model Asuhan Keperawatan Profesional Tim Terhadap Kualitas Pelayanan Keperawatan Di Bangsal Pria Rsud Datoe Binangkang Kabupaten Bolaang Mongondow.e-Jurnal Keperawatan.5(2).5-7

Butar-Butar, J., \& Simamora, R. H.

(2016). Hubungan Mutu Pelayanan Keperawatan dengan Tingkat Kepuasan Pasien Rawat Inap di RSUD Pandan Kabupaten Tapanuli Tengah. Jurnal Ners Indonesia, 6(1), 50-63.

Khamida, K., \& Mastiah, M. (2015).

Kinerja Perawat Dalam Memberikan Asuhan Keperawatan Berpengaruh Terhadap Kepuasan Pasien Rawat Inap. Journal of Health Sciences, $8(2)$.

Mastini I. (2013).

Hubungan Pengetahuan, Sikap, Beban Kerja Dengan Kebaikan Pendokumentasian Asuhan Keperawatan di RSUP Sanglah
Denpasar. Denpasar: Universitas Udayan

Sari, I. P. (2016).

Hubungan Pengetahuan Perawat Tentang Model Asuhan Keperawatan Metode Tim Dengan Implementasinya Di Ruang Bedah Flamboyan Rsud Dr Soetomo Surabaya. Medica Majapahit, 8(2), 74-79.

Simamora, R. H. (2005).

Hubungan Persepsi Perawat Pelaksana Terhadap Penerapan Fungsi Pengorganisasian Yang Dilakukan Oleh Kepala Ruangan Dengan Kinerjanya Diruang Rawat Inap RSUD Koja Jakarta Utara (Doctoral dissertation, Tesis FIK UI, Tidak dipublikasikan).

Sitorus,R . (2013).

Dampak Implementasi Model Praktik Keperawatan Profesional Terhadap Mutu Asuhan Keperawatan Di Rumah Sakit. Jurnal Keperawatan Indonesia . 7(2).42-45 
Syafrini, R. (2015).

Efektivitas Implementasi Asuhan Keperawatan Isolasi Sosial Dalam Mpkp Jiwa Terhadap Kemampuan Klien. Jurnal Ners, 10(1), 175-182.

Wulandri,P.et.al.(2016).

Faktor-Faktor Yang Berhubungan Dengan Pendokumentasian Asuhan Keperawatan Di Rumah Sakit Jiwa. NERS JURNAL KEPERAWATAN.12(2).137-139 